\title{
Applied research for enhancing human well-being and environmental stewardship: using complexity thinking in Southern Africa
}

\author{
Carolyn G. Palmer ${ }^{1}$, Reinette Biggs ${ }^{2,3}$ and Graeme S. Cumming ${ }^{4}$
}

Key Words: complexity; relational; stewardship; sufficiency; well-being

Humans all over the planet are struggling and aspiring to engage with the scale and scope of the challenge of achieving human well-being and environmental stewardship for all. This special feature presents the products of processes in Southern Africa that have explored the potential use of complexity approaches to tackling the substantial social-ecological challenges in the region. Although the papers composing the special feature draw mainly on South African case studies, the thinking and participation in development processes were inclusive of the broader region.

A concept that emerges through the papers is the inevitable conflation of human well-being and justice, and together they point toward social and ecological justice as an expression of human well-being, founded on environmental stewardship. Over the time the constituent papers have emerged, Mark Swilling and Eve Annecke have produced a most elegantly written and argued book Just Transitions (Swilling and Annecke 2012) that foregrounds the justice theme, deepens and complements several of the perspectives collectively presented in this feature, particularly complexity-based research, and adds an important economics lens.

Succinctly, the conceptual framing of the feature is grounded in recognizing the implications of a conscious awareness of socialecological systems as complex systems (Cilliers 2000, Audouin et al. 2013, Cilliers et al. 2013). This conscious apprehension embraces transdisciplinary, action-research approaches that are complexity-consistent, to gain insights and marshal action toward social and ecological justice (Swilling and Annecke 2012).

Southern Africa offers a compelling context from which to reflexively engage with the challenge of sustainable socialecological justice and well-being. The subcontinental region has a dramatic social ecology encompassing the emergence of humanity, diaspora, multiple colonizations, and in South Africa, an unexpectedly peaceful democratic transition. Generous natural resources were fought over and used, and with time, violence and injustice were embodied, starkly, for example, in the South African apartheid regime. Later, negotiation triumphed, and a heady process of building a renewed South African society emerged. Through this, people of all sorts engaged with each other and with their environment in a process of learning to live together in a particular place.

In the present context, Southern Africa is characterized by widespread poverty adjacent to extravagantly consumptive lifestyles.
South Africa has the highest Southern African GINI Index (range 42.7-61.3, mean 51.28; http://data.worldbank.org/indicator/SI. POV.GINI). There are still rich natural resources, and a range of transitions between variously generated incomes ranging from natural resource extraction, agricultural and industrial production, to natural-resource-based local livelihoods and ecotourism. These enterprises have divergent and often competing goals, with misaligned timescales for sustainability and profitability (Swilling and Annecke 2012). At the same time, there remains a strong mosaic of relatively intact ecosystems with structural and functional biodiversity, interspersed with rapidly deteriorating ecosystems, and concomitant loss of ecosystem services (CSIR 2012).

From this context, the authors have engaged with the task of assembling a range of conceptual, theoretical, and methodological tools with which to engage seemingly intractable situations characterized by threats to social and ecological wellbeing. The particular pathway to the special feature began in 2009 , when a group of researchers gathered in Skukuza, Kruger National Park, South Africa. Each brought their own life and professional journeys, and each was passionate about contributing practically and intellectually to explore the challenge of sustainable social-ecological well-being. Common themes were recognitions of the need for transdisciplinary approaches, and the value of concepts including resilience, complex social-ecological systems, and strategic adaptive management (Rogers and Luton 2011). The meeting resulted in the founding of the South African National Research Foundation (NRF) and supporting the Akili Complexity and Integration and Initiative. Akili is a ki-Swahili word for wise knowing. It was chosen to signify the importance of the broadest African context, and the concept of wisdom, which integrates knowledge about how the world works with deep emotional insight about how this knowledge can be justly used to advance human well-being.

Akili was located in the Applied Research and Innovation Directorate of the NRF, and was formally motivated by the argument that research output and uptake require innovative processes that take account of the context for research processes and products. The initiative brought together a rich mix of researchers and practitioners across South Africa, with widely varying philosophies, theories, knowledge, concepts, experiences, and practices to address the explicit challenge of sustainable social-ecological well-being. Akili processes: (i) emphasized

${ }^{1}$ Unilever Centre for Environmental Water Quality, Institute for Water Research, Rhodes University, South Africa, ${ }^{2}$ Stockholm Resilience Centre, Sweden, ${ }^{3}$ Centre for Studies in Complexity, Stellenbosch University, South Africa, ${ }^{4}$ Percy FitzPatrick Institute, University of Cape Town, South Africa 
research in the service of society, that positively influences socialecological well-being, takes account of values, and that facilitates change toward sustainability; (ii) took care to mix early career and experienced researchers and practitioners so as to encourage concurrent excellence and innovation; and (iii) communicated a set of enabling transdisciplinary practice principles (Palmer et al. 2007):

- Tolerate and even welcome discomfort and unresolved tensions; they are often gateways to knowledge and trust.

- Be sensitive to "aha" moments or insights, and note that irritation and conflict often signal moments of insight and a learning opportunity.

- Engage with balanced generosity; listen and share.

- Practice tolerance, build integrity and mutual trust.

- Be sensitive to "arrivals" of both people and ideas.

- Create and use reflective opportunities.

- Manage discontinuities (people come and go, and arrangements change suddenly).

- Sustain enquiry (keep going when it is tough).

- Be conscious that everyone involved in the process is a whole, multidimensional person, with the potential to engage with their whole self and many ways of knowing.

After a colloquium and national workshop, groups of Akili participants agreed to collaborate to write a series of papers that would exemplify South African learning and experience in Applied Research for Enhancing Human Well-Being and Environmental Stewardship: Using Complexity Thinking in Southern Africa. The process was both exciting and frustrating. Some really hard-working groups could not find a persuasive, substantive voice and other groups that finally submitted manuscripts were not part of the Akili process. However, five years after initiation, this issue stands as a record of a collective social learning process and reveals some of the innovative thinking and practice to emerge from southern Africa in applying complexity based approaches to advancing social-ecological stewardship and human well-being. The NRF Akili initiative has subsequently been closed down, but in addition to this special feature, its legacy has been the Southern African Complexity Forum and the establishment of the Southern African Program on Ecosystem Change and Society (SAPECS), a network of regional transdisciplinary social-ecological case studies linked to the international ICSU Program on Ecosystem Change and Society (Carpenter et al. 2012).

The lead article in this special feature is contributed by Cilliers et al. (2013). It was published posthumously and stands as a tribute to the substantive contribution of the philosopher, Professor Paul Cilliers of Stellenbosch University, to complexity as a basis from which to engage with the trenchant issues of humanity living well on the planet (Cilliers 2000, 2001). The paper offers a clear exposition of Cilliers' perspectives and contribution to complexity thinking, framed, in this instance, in the context of natural resource management. It offers a crisp foundation to understanding that the world comprises complex systems, and that the implications of complex systems are critical to the future.
The Cilliers et al. (2013) foundation is built on by Audouin et al. (2013) who further explore complexity, bringing the notion of critical complexity, and the valuable contribution of emphasizing process and underlying principles. Rogers et al. (2013) add depth to an understanding of learning processes within complex socialecological system research and practice, highlighting the role of "habits of mind," and both Pollard et al. (2014) and Freitag et al. (2014) take the thinking and theory of applied research in socialecological systems into the complexity of practice. Biggs et al. (2015) present a series of examples that illustrate four general strategies for managing social-ecological systems in the face of uncertainty, based on innovations and experiences in the region.

These thoughtful pieces provide insights into the detail of applying these approaches in the real word. The papers by Malinga et al. (2013), Pad-Khene et al. (2013), and Urgenson et al. (2013) exemplify and expand on the role of stakeholder and participation and use of the notion of ecosystem services, all emerging foci of research that aims to engage with complex, realworld social-ecological issues to further social-ecological wellbeing.

We suggest that the particular perspective of complexity thinking in these papers enables the distillation of a few general lessons:

- Appreciation of complexity enables a focus on relational issues. The processes between components are as important, and functionally definitive, as the nature of the components;

- Relationality in its turn, is a foundation of social learning, the process whereby the concurrent learning characteristic among transdisciplinary researchers and practitioners emerges in reinforcing feedback loops of learning and practice;

- Feedback is another fundamental characteristic of complex systems, which, together with relationality, can be discerned sensitively, using systemic approaches (Pollard et al. 2014). Ison (2010) demonstrates the reinforcing feedback between social learning and systemic appreciation;

- Values are an emergent property of human society embedded in the natural world. As Swilling and Annecke (2012) suggest, "sufficiency" may be a value, to be socially learned through practice, becoming a habit of mind, expressed in a suite of behavior, necessary for social and ecological well-being, and justice.

A final word draws on the opportunity this feature offers to express in a nuanced way the philosophy of Paul Cilliers. In presenting the world as a complex, multiple system of systems Cilliers placed relationship at the centre, both in terms of the quality and nature of the processes between elements, and in terms of the complete reality and humanity's incomplete insight into and knowledge of that reality (Fig. 1). His primary philosophical tools were modesty and provisionality. As we seek a mosaic of methodological pathways to knowledge and understanding, each step and elucidation needs to be accepted with all its known and unknown limitations. The general lessons that emerge from the process come from exploring the several ways in which we come to know and derive meaning in the world, bringing alongside one another interesting configurations: the customary intellectual approach of academia, the contribution of an emerging 
Fig. 1. A representation by guest editor, Carolyn Palmer, of the perspectives presented in the special feature. The elements were derived from an early draft of the paper by Cilliers et al. (2013).
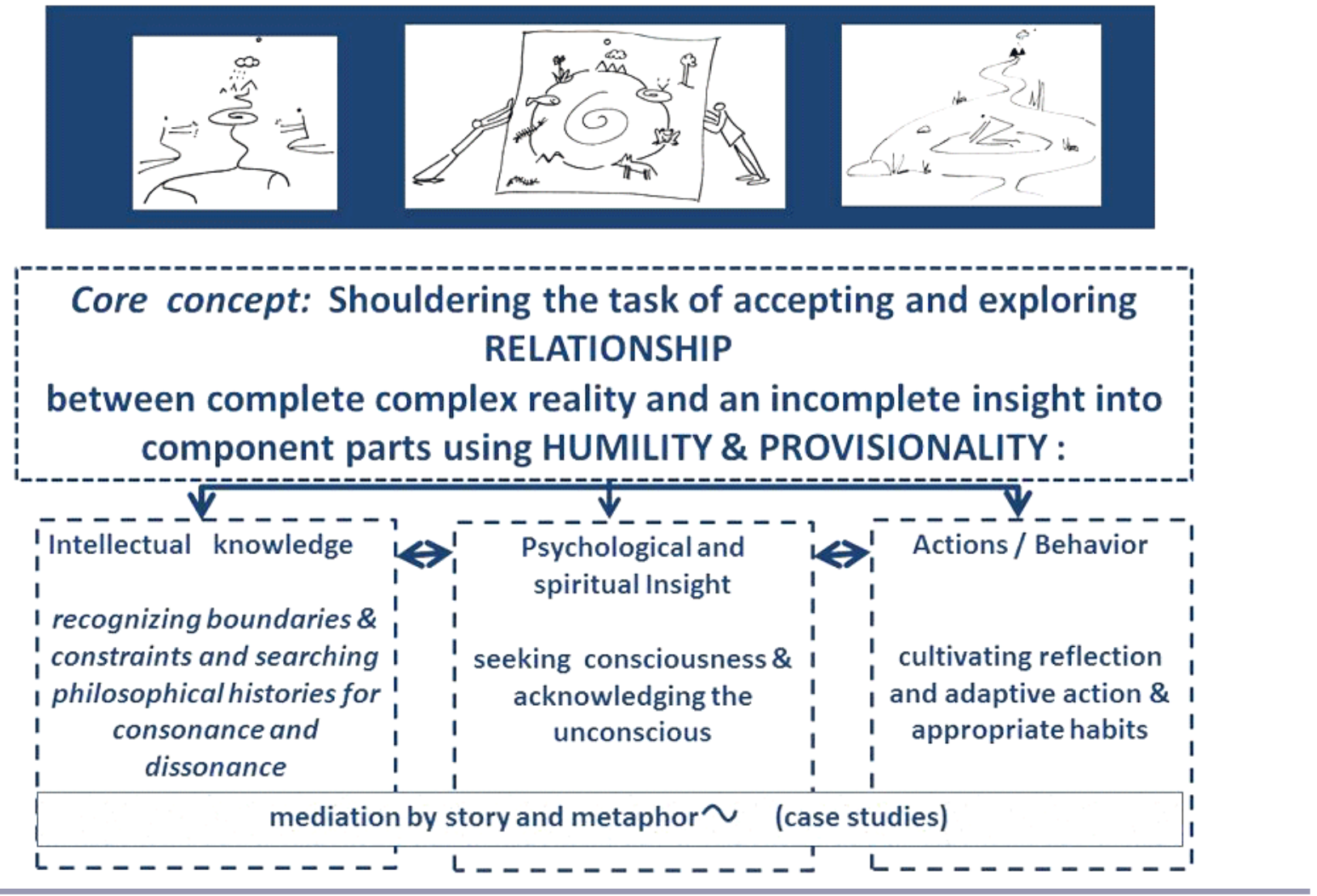

understanding of both conscious and unconscious processes, and the implacable world of acting and taking responsibility for action. In some ways, recognition of the complex and systemic nature of the world has come about through a willingness to become more conscious and attentive, especially to those observations and experiences that do not make sense in terms of a modern rationality. Cilliers challenges us to recognize and take responsibility for how we act individually and collectively and be open to learning and change, and to the conversion of our deeply held habits of mind (Rogers et al. 2013) and habitus, which includes our encultured and often taken for granted socio-cultural practices (Bourdieu 1990). This hard road seems best mediated by the stories we tell one another and the quality of our listening.

Responses to this article can be read online at: http://www.ecologyandsociety.org/issues/responses. php/7087

\section{Acknowledgments:}

This special feature was supported by the South African National Research Foundation: The Akili Complexity and Integration Initiative within Applied Research and Innovation. The funding enabled author groups to meet over time, and for researchers, including early career researchers and students, to co-publish.

\section{LITERATURE CITED}

Audouin, M., R. Preiser, S. Nienaber, L. Downsborough, J. Lanz, and S. Mavengahama. 2013. Exploring the implications of critical complexity for the study of social-ecological systems. Ecology and Society18(3): 12. http://dx.doi.org/10.5751/ES-05434-180312

Biggs, R., C. Rhode, S. Archibald, L. M. Kunene, S. S. Mutanga, N. Nkuna, P. O. Ocholla, and L. J. Phadima. 2015. Strategies for managing complex social-ecological systems in the face of uncertainty: examples from South Africa and beyond. Ecology and Society 20(1): 52. http://dx.doi.org/10.5751/ES-07380-200152

Bourdieu, P. 1990. The logic of practice. Translated by R. Nice. Stanford University Press, Stanford, California, USA.

Carpenter, S. R., C. Folke, A. Norström, O. Olsson, L. Schultz, B. Agarwal, P. Balvanera, B. M. Campbell, J. C. Castilla, W. Cramer, R. DeFries, P. Eyzaguirre, T. P. Hughes, S. Polasky, Z. Sanusi, R. J. Scholes, and M. Spierenburg. 2012. Program on ecosystem change and society: an international research strategy for integrated social-ecological systems. Current Opinion on Environmental Sustainability 4:134-138. http://dx.doi.org/10.1016/ j.cosust.2012.01.001 
Cilliers, P. 2000. What can we learn from a theory of complexity? Emergence 2(1):23-33. http://dx.doi.org/10.1207/S15327000EM0201_03

Cilliers, P. 2001. Boundaries, hierarchies and networks in complex systems. International Journal of Innovation Management 5 (2):135-147. http://dx.doi.org/10.1142/S1363919601000312

Cilliers, P., H. C. Biggs, S. Blignaut, A. G. Choles, J. S. Hofmeyr, G. P. W. Jewitt, and D. J. Roux. 2013. Complexity, modeling, and natural resource management. Ecology and Society 18(3): 1. http://dx.doi.org/10.5751/ES-05382-180301

Council for Scientific and Industrial Research (CSIR). 2012. CSIR natural resources and environment annual research and impact report. CSIR, Pretoria, South Africa. http://www.csir.co. za/nre/docs/NRE\%20RESEARCH\%20REPORT.pdf

Freitag, S., H. Biggs, and C. Breen. 2014. The spread and maturation of strategic adaptive management within and beyond South African national parks. Ecology and Society 19(3): 25. http://dx.doi.org/10.5751/ES-06338-190325

Ison, R. 2010. Systems practice: How to act in a climate-change world. Springer, London, UK. http://dx.doi.org/10.1007/978-1-84996-125-7

Malinga, R., L. J. Gordon, R. Lindborg, and G. Jewitt. 2013. Using participatory scenario planning to identify ecosystem services in changing landscapes. Ecology and Society 18(4): 10. http://dx.doi.org/10.5751/ES-05494-180410

Pade-Khene, C., R. Luton, T. Jordaan, S. Hildbrand, C. Gerwel Proches, A. Sitshaluza, J. Dominy, W. Ntshinga, and N. Moloto. 2013. Complexity of stakeholder interaction in applied research. Ecology and Society 18(2): 13. http://dx.doi.org/10.5751/ ES-05405-180213

Palmer, C. G., J. Gothe, C. Mitchell, C. Reidy, K. Sweetapple, S. Mclaughlin, G. Hose, M. Lowe, H. Goodall, T. Green, D. Sharma, S. Fane, K. Brew, and P. Jones. 2007. Finding integration pathways: a transdisciplinary (TD) approach for the Upper Nepean Catchment. Proceedings of the 5th Australian Stream Management Conference. Charles Sturt University, Thurgoona, New South Wales, Australia. [online] URL: http://www.csu.edu. au/ data/assets/pdf file/0011/748415/Palmer Carolyn 306.pdf

Pollard, S., H. Biggs, and D. R. Du Toit. 2014. A systemic framework for context-based decision making in natural resource management: reflections on an integrative assessment of water and livelihood security outcomes following policy reform in South Africa. Ecology and Society 19(2): 63. http://dx.doi.org/10.5751/ ES-06312-190263

Rogers, K. H., and R. Luton. 2011. Strategic adaptive management as a framework for implementing integrated water resource management in South Africa: report to the Water Research Commission. WRC Report No. KV 245/10. Gezina, South Africa.

Rogers, K. H., R. Luton, H. Biggs, R. Biggs, S. Blignaut, A. G. Choles, C. G. Palmer, and P. Tangwe. 2013. Fostering complexity thinking in action research for change in social-ecological systems. Ecology and Society 18(2): 31. http://dx.doi.org/10.5751/ ES-05330-180231
Swilling, M., and E. Annecke. 2012. Just transitions. UCT Press, Cape Town, South Africa.

Urgenson, L. S., H. E. Prozesky, and K. J. Esler. 2013. Stakeholder perceptions of an ecosystem services approach to clearing invasive alien plants on private land. Ecology and Society 18(1): 26. http:// dx.doi.org/10.5751/ES-05259-180126 